\title{
NIEMIECKIE ŻYCIE, POLSKA KULTURA - CZYNNIKI RÓŻNICUJĄCE POZIOM KORZYSTANIA Z NIEMIECKICH TREŚCI KULTURY WŚRÓD MIGRANTÓW Z POLSKI W NIEMCZECH
}

Agnieszka JERAN (Uniwersytet im. Adama Mickiewicza w Poznaniu) ORCID: 0000-0002-9670-8585

\section{Wprowadzenie}

Historia migracji Polaków liczy sobie przynajmniej dwieście lat ${ }^{1}$, a kolejne fale migracji można zgrupować na wiele sposobów, chociażby wg przyczyn wyróżniając uchodźctwo polityczne, emigrację ekonomiczną, wojskowo-osiedleńczą czy związaną z akcesją Polski do Unii Europejskiej. Paweł Boski zauważa unikalność polskich doświadczeń w tym zakresie, zauważając, że ,żaden z krajów europejskich nie ma podobnego, ciągłego przez 200 lat, doświadczenia wyjazdów emigracyjnych. [...] dzieje się tak zarówno w okresach braku suwerenności, jak i wolności; nędzy, jak i względnej prosperity",2.

Migracje, w których krajem docelowym były Niemcy, mają przynajmniej równie długą historię. Michał Nowosielski ${ }^{3}$ przedstawia dziesięć kolejnych fal, poczynając od początku XIX w., a na migracjach poakcesyjnych kończąc. W przypadku tego kierunku

\footnotetext{
${ }^{1}$ P. Boski, Kulturowe ramy zachowań społecznych. Podręcznik psychologii międzykulturowej, Warszawa 2009.

${ }^{2}$ Tamże, s. 521.

${ }^{3}$ M. Nowosielski, Polacy w Niemczech. Stan i perspektywy badań, Przegląd Zachodni 2012 nr 3, s. 3-28.
} 
migracji oszacowanie jej przebiegu i liczebności migrantów utrudnia zmienność sytuacji geopolitycznej (związana z przesunięciami granic, w wyniku których konkretna miejscowość pochodzenia danej osoby bywała miejscem niemieckim lub polskim, niezależnie od tożsamości). W efekcie analiza uwzględniająca kolejne fale i ich specyficzne uwarunkowania prowadzi do zróżnicowanych oszacowań liczebności migrantów z Polski w Niemczech, przy czym sytuację dodatkowo komplikuje problem zastosowania adekwatnej nazwy. Na podstawie badań prowadzonych przez niemieckie instytucje, przy najszerszej definicji są to „osoby o polskim podłożu migracyjnym”, a ich liczbę szacuje się na około $1,3 \mathrm{mln}^{4}$. Inne funkcjonujące określenia to chociażby Polonia ${ }^{5}$ (co zakłada jednak pewien stopień samoorganizacji migrantów w miejscu pobytu), Polacy w Niemczech czy polska diaspora ${ }^{6}$, zaś uwzględniając kwestie zarówno pochodzenia, jak i aktualnego obywatelstwa można wyróżnić przynajmniej pięć grup, od obcokrajowców (Polaków z polskim obywatelstwem przebywających w Niemczech) przez bezpaństwowców po przesiedleńców ${ }^{7}$. Użycie celowo szerokiego określenia „migranci z Polski w Niemczech" wykorzystuje możliwie inkluzywne zdefiniowanie badanej populacji, do której należeli „obywatele Polski mieszkający w RFN, obywatele niemieccy polskiego pochodzenia oraz osoby niemieckiego pochodzenia identyfikujące się z polską kulturą i językiem" $"$.

Doświadczenie pobytu migracyjnego wiąże się z doświadczaniem oddziaływania przynajmniej dwóch porządków - społecznych, instytucjonalnych i kulturowych, tj. własnego porządku migranta, stanowiącego wyraz jego socjalizacji w kraju pochodzenia (a więc obejmującego wartości, przekonania, nawyki typowe dla kultury kraju pochodzenia) oraz porządku kraju przyjmującego, który w różnym zakresie i w różnych obszarach odbiega od pierwszego. Im bliższe sobie kulturowo, aksjonormatywnie, językowo oba kraje, tym różnica ta jest mniejsza. Sposoby radzenia sobie z nią określić można jako strategie adaptacji, a ich wybór i stosowanie (w tym efektywność) zależą od szeregu czynników, obejmujących chociażby politykę migracyjną kraju przyjmującego ${ }^{9}$, otwartość społeczeństwa przyjmującego wobec migrantów, sytuację polityczną obu krajów, a także podatność (odporność) na zmianę światopoglądów pod wpływem funkcjonowania w innej kulturze ${ }^{10}$ (poziom samosterowności), a także zasoby osobiste (np. kapitał kulturowy) migranta.

Adaptację czy też stanowiące jej efekt procesy integracji migrantów ze społeczeństwem przyjmującym można rozpatrywać z kilku różnych perspektyw, do których należą spojrzenia poprzez integrację psychologiczną czy kulturową, ale też zawodową czy ekonomiczną. Szczególne znaczenie w świetle analizowanych badań ma aspekt

\footnotetext{
${ }^{4}$ Tamże, s. 13.

${ }^{5}$ M. Schulz, Migracje ekonomiczne Polaków do Niemiec, Humanizacja Pracy 2013 nr 272, s. $73-86$.

${ }^{6}$ M. Lesińska, Polska diaspora, Polonia, emigracja. Spory pojęciowe wokót skupisk polskich za granica, The Polish Migration Review 2018 nr 1 (3), s. 9-23.

${ }^{7}$ W. Nowak, Problemy tożsamości spotecznej Polaków mieszkających w Niemczech, Przegląd Zachodni $2013 \mathrm{nr} 3$, s. 258.

${ }^{8}$ A. Jeran, W. Nowak, M. Nowosielski, Migranci z Polski w Niemczech - aspekty kulturowe. Raport z bada, Warszawa 2019, s. 10 (wersja niemieckojęzyczna: Migrantinnen und Migranten aus Polen in Deutschland - kulturelle Aspekte. Studienbericht, Warszawa 2019).

${ }^{9}$ R. Suchocka, Migranci pomiędzy dwiema kulturami i pomiędzy dwiema strategiami adaptacyjnymi, Ruch Ekonomiczny, Prawniczy i Socjologiczny 2013 z. 1, s. 249-265.

${ }^{10}$ E. Nycz, Dziedzictwo kulturowe a adaptacja starych i nowych migrantów z Polski w społeczeństwie niemieckim, Zeszyty Naukowe Politechniki Śląskiej, seria: Organizacja i Zarządzanie $2018 \mathrm{nr} 126$, s. 161-172.
} 
kulturowy, jednak uwikłanie w kwestie włączenia w kulturę aspektów tożsamościowych sprawia, że istotne staje się także spojrzenie na adaptację psychologiczną, co wymaga uwzględnienia takich pojęć, jak szok kulturowy i stres akulturacyjny, a także indywidualnych strategii akulturacyjnych jednostek, wpisujących się w cztery możliwości: marginalizację, separację, asymilację i integrację ${ }^{11}$.

W kontekście strategii i akulturacyjnego stanu jednostki, bezpośrednio w odniesieniu do kultury można odwołać się do wprowadzonego przez Antoninę Kłoskowską pojęcia walencji kulturowej i jej rodzajów, które mogą charakteryzować orientację kulturową migrantów. Sama walencja definiowana jest jako „poczucie związku z kulturą etniczną lub narodową, uznawaną za własną, stanowiącą dziedzictwo kulturowe własnej grupy" "12, przy czym grupę tę stanowi według Kłoskowskiej przede wszystkim wspólnota narodowa. Walencja kulturowa, zarówno w sensie jej rodzaju, który wskazuje na sposób rozwiązania problemów adaptacyjnych, jak i szczegółowo jako odniesienie do konkretnej kultury narodowej, pozostaje istotna dla procesów uczestniczenia w kulturze, wiąże się bowiem bezpośrednio z preferencją w zakresie języka i zakorzenienia narodowego treści kultury i jest $\mathrm{w}$ związku tym istotna $\mathrm{w}$ badaniach doświadczeń migrantów ${ }^{13}$. W odniesieniu do rodzajów walencji wskazuje się na cztery typy: uniwalencję (identyfikację z jedną kulturą), biwalencję (identyfikację z dwiema kulturami, w sytuacji migracyjnej jest to kultura kraju pochodzenia i kraju przyjmującego) i jako jej poszerzenie — poliwalencję (przyswojenie i identyfikacja z wieloma kulturami narodowymi), a także ambiwalencję (niejasność lub niepewność co do identyfikacji kulturowej). Warto w tym miejscu podkreślić, że w omawianym badaniu przyjęto strategię swego rodzaju „wymuszenia” u respondentów dokonania jednoznacznego wyboru czyli konstruując narzędzia dopuszczono tylko uniwalencję. Ten zabieg z jednej strony niewątpliwie przyczynia się do uproszczenia uzyskiwanego obrazu identyfikacji kulturowej badanych migrantów, z drugiej jednak skłaniał ich do swoistego oszacowania, jakie miejsce zajmują pomiędzy kulturami kraju pochodzenia a kraju obecnego zamieszkiwania (pytanie umożliwiało także odwołanie do kultury o szerszym zasięgu tj. europejskiej).

Podstawowym zjawiskiem objętym badaniem był aspekt kulturowego funkcjonowania migrantów, ujęty jako ich uczestnictwo w kulturze. Zgodnie z definicją Kłoskowskiej, uczestnictwo kulturalne obejmuje „,czynności formułowania oraz odbierania i interpretowania symbolicznych przekazów" "14 przy czym w większości są to procesy odbioru opisywane w odniesieniu do wykorzystywanych kanałów (mediów) i wybranych cech treści (przede wszystkim w zakresie języka, w którym treści te są odbierane). Samo pojęcie uczestnictwa w kulturze podlega krytyce, osadzonej w identyfikacji przemian współczesnej aktywności kulturalnej i samej kultury. Uczestnictwo uznawano za pojęcie martwe ${ }^{15}$, a przemiany sposobów korzystania z kultury, splecenie aktywno-

${ }^{11} \mathrm{P}$. Boski, Kulturowe ramy zachowań spotecznych, s. 533-535.

12 A. Kłoskowska, Kultury narodowe u korzeni, Warszawa 2012, s. 162.

${ }^{13}$ O. Dawidenko, Polonia na tle procesów narodowościowych Kazachstanu. Wymiary identyfikacji narodowej, http://janek.uek.krakow.pl/ limes/files/el1(1)2002/od_limes1(1).pdf [dostęp: 10.01.2020]; K. Slany, S. Strzemecka, Who are we? Cultural valence and childrens narratives of national identifications, Central and Eastern European Migration Review $2016 \mathrm{nr} 1$ (5), s. 13-34, http://doi.org/10.17467/ceemr.2016.03.

${ }_{14}$ A. Kłoskowska, Społeczne ramy kultury. Monografia socjologiczna, Warszawa 1972 , s. 129.

${ }^{15}$ M. Filiciak, M. Danielewicz, M. Halawa, P. Mazurek, A. Nowotny, Młodzi i media. Nowe media a uczestnictwo w kulturze, Warszawa 2010, s. 8. 
ści twórczej i odbiorczej czy zanik tradycyjnych kanałów przekazu kulturowego za odpowiedzialne za jego co najmniej nieadekwatność. Jednak mimo wskazywania na faktyczną nieadekwatność pewnych stosowanych miar, na zmiany wynikające z cyfryzacji, usieciowienia, wizualizacji czy globalizacji, w podstawowym ujęciu uczestnictwo jako formułowanie, odbieranie i interpretowanie przekazów symbolicznych nie zanika, stanowi bowiem podstawowy, komunikacyjny proces tworzenia społeczeństwa. W praktyce badawczej definicje uczestnictwa są różne ${ }^{16}$ - mniej lub bardziej adekwatne do przemian sfery kultury, twórczości i odbioru, co jednak jest raczej wyrazem trafności procedur niż samego pojęcia ${ }^{17}$.

\section{Metoda $^{18}$}

W badaniu wykorzystano ankietę internetową, zachęcając potencjalnych uczestników do udziału w niej w dniach od 17 do 31 stycznia 2018 r. Zaproszenia do badania wyświetlano użytkownikom ogólnopolskich portali informacyjnych po zidentyfikowaniu połączenia jako przychodzącego $\mathrm{z}$ terenu Niemiec oraz portali polonijnych, skierowanych do migrantów z Polski w Niemczech. Szczegółowy opis procedur, osób badanych i narzędzia zawiera raport z przeprowadzonej ankiety.

Wykorzystywana w badaniu ankieta internetowa zawierała szereg pytań odnoszących się do różnych aspektów uczestnictwa w kulturze z uwzględnieniem specyfiki sytuacji migracyjnej, tj. w szczególności kwestie języka, w którym badani korzystają z treści kultury, barier uczestnictwa w kulturze czy kanałów pozyskiwania informacji o wydarzeniach kulturalnych. W opisie sytuacji społeczno-demograficznej uwzględniano specyfikę sytuacji migracyjnej, m.in. w zakresie typu i czasu migracji, relacji z migrantami i kontaktów z Polską.

Na potrzeby analiz obok rozkładów odpowiedzi na poszczególne pytania wykorzystywano także indeksy i wskaźniki utworzone na podstawie zestawów pytań. Był to w szczególności wskaźnik nasycenia treści kultury językiem polskim/niemieckim, który stanowi średnią oszacowanych przez badanych udziałów książek w księgozbiorze, książek przeczytanych (w ciągu roku), czytanej prasy, oglądanych programów telewizyjnych i filmów w danym języku. Wskaźnik obejmuje wartości od zera do stu procent.

\section{Wyniki}

Osoby badane. W przeprowadzonym badaniu odpowiedzi udzieliło 1249 osób, z czego 52,5\% (656 osób) stanowiły kobiety o średnim wieku 39,3 lat. Większość badanych posiadała polskie obywatelstwo $(96 \%, 77 \%$ wyłącznie polskiego), wyższe wykształcenie $(83,1 \%)$, aktywność zawodową $(81,2 \%)$ i dobrą sytuację materialną $(69,6 \%)$. Większość

${ }^{16}$ Por.: P. Kisiel, Wspótczesne wzory uczestnictwa w kulturze, [w:] Kultura a rozwój, red. J. Hausner, A. Karwińska, J. Purchla, Warszawa 2013, s. 345-360.

${ }^{17}$ A. Jeran, Prolegomena: glos w obronie tradycji albo dlaczego uczestnik to nie zombie, [w:] Diagnoza systemu kultury Bydgoszczy, red. taż, Bydgoszcz 2012, s. 11-24.

${ }_{18}$ Projekt „Migranci z Polski w Niemczech — aspekty kulturowe” realizowany był w latach 2016-2018. Instytucją wnioskującą oraz głównym wykonawcą projektu był początkowo Instytut Zachodni w Poznaniu, a od 2017 r. Ośrodek Badań nad Migracjami Uniwersytetu Warszawskiego (OBM UW). Niemieckim partnerem przedsięwzięcia był Deutsches PolenInstitut z Darmstadt (DPI). Projekt wspierany był przez Polsko-Niemiecką Fundację na rzecz Nauki, http://www.migracje.uw.edu.pl/projects/migranci-z-polski-w-niemczech-aspekty-kulturowe/ [dostęp: 10.01.2020]. 
badanych deklarowała znajomość języka niemieckiego dobrą (35\%) i zaawansowaną $(41,7 \%)$, tylko w pojedynczych przypadkach wykazano brak znajomości, zaś $22,1 \%$ badanych wskazało na posługiwanie się językiem niemieckim na poziomie podstawowym.

Uczestnictwo w kulturze. Połowa badanych wyrażała zadowolenie z własnego uczestnictwa w kulturze, zaś 30,9\% deklarowało ambiwalencję. Przekładając poziom uczestnictwa na poziom wydatków, można wskazać, że przeciętnie (jako wydatki miesięczne na członka gospodarstwa domowego) był to poziom 50 euro (średnia 54,4; mediana 50,0) — przy bardzo dużym zróżnicowaniu (od 0 do 500 euro). Przeciętny czas przeznaczony na korzystanie $\mathrm{z}$ ofert instytucji kultury i czytanie książek wynosił nieco ponad 1,5 godziny tygodniowo, ale należy do niego doliczyć kilka do kilkunastu godzin oglądania telewizji (łącznie 52,9\% badanych deklarowało oglądanie telewizji do dwóch godzin dziennie) — wraz z czasem na czytanie prasy (średnio 5,8 godziny) daje to łącznie około dwudziestu godzin kontaktu z treściami kultury tygodniowo.

Sytuację migracyjną w kontekście uczestnictwa w kulturze charakteryzuje możliwość (lub konieczność) kontaktu z treściami kultury zarówno w języku kraju pochodzenia (polskim), jak i kraju pobytu (niemieckim). W odniesieniu do poszczególnych kanałów kontaktu z kulturą znaczenie obu tych języków było różne — udział języka polskiego sięgał 70\% w przypadku czytanych książek, zaś w przypadku oglądania telewizji pozostawał na poziomie poniżej $50 \%$.

Tabela 1. Charakterystyka językowa korzystania z przekazów kultury.

\begin{tabular}{|l|c|c|c|c|}
\hline \multicolumn{1}{|c|}{ Kategoria } & $\begin{array}{c}\text { Mediana } \\
\text { udziału } \\
\text { języka } \\
\text { polskiego }\end{array}$ & $\begin{array}{c}\text { Średnia udziału } \\
\text { języka } \\
\text { polskiego }\end{array}$ & $\begin{array}{c}\text { Mediana udziału } \\
\text { języka } \\
\text { niemieckiego }\end{array}$ & $\begin{array}{c}\text { Średnia udziału } \\
\text { języka } \\
\text { niemieckiego }\end{array}$ \\
\hline $\begin{array}{l}\text { Domowy księgozbiór } \\
\text { (liczba posiadanych } \\
\text { książek) }\end{array}$ & $70 \%$ & $65,6 \%$ & $20 \%$ & $28,1 \%$ \\
\hline $\begin{array}{l}\text { Przeczytane w ciągu } \\
\text { minionych 12 miesięcy } \\
\text { książki }\end{array}$ & $80 \%$ & $68,9 \%$ & $10 \%$ & $24,8 \%$ \\
\hline $\begin{array}{l}\text { Czas oglądania telewizji } \\
\text { (dziennie) }\end{array}$ & $40 \%$ & $43,9 \%$ & $50 \%$ & $52,2 \%$ \\
\hline $\begin{array}{l}\text { Czas na czytanie prasy } \\
\text { (tygodniowo) }\end{array}$ & $50 \%$ & $53,4 \%$ & $40 \%$ & $41,9 \%$ \\
\hline $\begin{array}{l}\text { Obejrzane w ciągu minio- } \\
\text { nych 12 miesięcy filmy }\end{array}$ & $50 \%$ & $51,2 \%$ & $25 \%$ & $37,2 \%$ \\
\hline
\end{tabular}

Źródło: obliczenia własne na podstawie badania. 
Wartości wskaźnika nasycenia treści kultury językiem niemieckim. Wyznaczony na podstawie wskazań zakresu korzystania $\mathrm{z}$ treści kultury masowej w języku niemieckim wskaźnik nasycenia przyjął wartości z pełnego potencjalnego zakresu. Wartość średnia wyniosła $35,2 \%$, dla połowy respondentów udział treści w języku niemieckim nie przekraczał $32 \%$, zaś co piętnasty $(6,8 \%)$ badany nie miał kontaktu z żadnym przekazem (czytanym lub oglądanym) w języku niemieckim. $Z$ drugiej strony udział ankietowanych, którzy wskazywali na kontakt tylko z treściami w języku niemieckim, był bardzo niewielki (pojedyncze wskazania), a zaledwie 2,8\% zadeklarowało udział $90 \%$ i wyższy. Poniżej przedstawiono szczegółowo rozkład wartości wskaźnika.

Tabela 2. Rozkład wartości wskaźnika nasycenia treści kultury językiem niemieckim.

\begin{tabular}{|r|r|r|r|}
\hline Przedział wartości & Częstość & Udział [\%] & Udział skumulowany [\%] \\
\hline 0 do 10,00 & 319 & 25,6 & 25,6 \\
\hline 10,01 do 20,00 & 131 & 10,5 & 36,2 \\
\hline 20,01 do 30,00 & 146 & 11,7 & 47,9 \\
\hline 30,01 do 40,00 & 152 & 12,2 & 60,1 \\
\hline 40,01 do 50,00 & 126 & 10,1 & 70,3 \\
\hline 50,01 do 60,00 & 112 & 9,0 & 79,3 \\
\hline 60,01 do 70,00 & 102 & 8,2 & 87,5 \\
\hline 70,01 do 80,00 & 73 & 5,9 & 93,3 \\
\hline 80,01 do 90,00 & 48 & 3,9 & 97,2 \\
\hline 90,01 do 100,00 & 35 & 2,8 & 100,0 \\
\hline Ogółem & 1244 & 100,0 & \\
\hline
\end{tabular}

Źródło: obliczenia własne na podstawie badania.

Zróżnicowanie charakterystyki językowej korzystania z przekazów masowych. Charakterystyka językowa treści kulturowych, z których korzystają migranci z Polski w Niemczech, była różnicowana, dla większości z nich obejmując udział około 1/3 treści w języku niemieckim. Dosyć oczywistym czynnikiem, odpowiadającym za zróżnicowane sięganie po treści w języku niemieckim, był poziom znajomości języka i tę relację charakteryzowały najsilniejsze zależności. Istotnym czynnikiem była także długość pobytu migracyjnego, a w dalszej kolejności wiek. Najmniejsze znaczenie miał poziom wydatków na uczestnictwo w kulturze. W zależności od wykorzystywanego medium stopień nasycenia językowego od poszczególnych cech migrantów jest przy tym różna — najsilniejsza w przypadku oglądanych filmów, a w dalszej kolejności czytanych książek. Potwierdzałoby to znaczenie nie tylko znajomości języka, ale też większej niezbędnej płynności korzystania z niego i osadzania komunikatów w kontekście, co jest trudniejsze w przypadku literatury czy filmów niż prasy, która silniej odnosi się do sytuacji bieżącej. 
Tabela 3. Korelacje między wybranymi charakterystykami migranta i jego uczestnictwa w kulturze a nasyceniem treści kultury językiem niemieckim.

\begin{tabular}{|c|c|c|c|c|}
\hline \multirow[b]{2}{*}{ Kategoria } & \multicolumn{4}{|c|}{ Czynniki } \\
\hline & $\begin{array}{l}\text { Deklarowany } \\
\text { poziom znajomo- } \\
\text { ści języka nie- } \\
\text { mieckiego }\end{array}$ & $\begin{array}{l}\text { Długość } \\
\text { pobytu }\end{array}$ & Wiek & $\begin{array}{l}\text { Wydatki na } \\
\text { uczestnictwo } \\
\text { w kulturze }\end{array}$ \\
\hline $\begin{array}{l}\text { Udział książek w języku } \\
\text { niemieckim w domowym } \\
\text { księgozbiorze }\end{array}$ & $0,451 * *$ & $0,460^{* *}$ & $0,229^{* *}$ & 0,054 \\
\hline $\begin{array}{l}\text { Udział książek w języku } \\
\text { niemieckim wśród } \\
\text { książek przeczytanych } \\
\text { w minionym roku }\end{array}$ & $0,465^{* *}$ & $0,462^{* *}$ & $0,255^{* *}$ & $0,080^{* *}$ \\
\hline $\begin{array}{l}\text { Udział oglądania } \\
\text { telewizji w języku } \\
\text { niemieckim }\end{array}$ & $0,448 * *$ & $0,280^{* *}$ & $0,215^{* *}$ & $0,088^{* *}$ \\
\hline $\begin{array}{l}\text { Udział czytanej prasy } \\
\text { w języku niemieckim }\end{array}$ & $0,328 * *$ & $0,252^{* *}$ & $0,115^{* *}$ & 0,040 \\
\hline $\begin{array}{l}\text { Udział oglądanych } \\
\text { filmów w języku } \\
\text { niemieckim }\end{array}$ & $0,517 * *$ & $0,442^{* *}$ & $0,281^{* *}$ & $0,108^{* *}$ \\
\hline $\begin{array}{l}\text { Wskaźnik nasycenia } \\
\text { treści kultury językiem } \\
\text { niemieckim }\end{array}$ & $0,542 * *$ & $0,469 * *$ & $0,278 * *$ & $0,097 * *$ \\
\hline
\end{tabular}

Znaczenie wykształcenia. Znaczenie kontekstu i wykształcenia jest istotne dla ogólnych wskaźników uczestnictwa w kulturze i w analizie sytuacji migrantów wykorzystano zróżnicowanie wg osiągniętego wykształcenia na poziomie wyższym. Odnosząc się do wskaźnika nasycenia treści kultury językiem niemieckim należy wskazać, że było ono istotnie (test U Manna-Whitneya) wyższe wśród osób z wykształceniem wyższym, osiągając średnią 36,3\% (wobec 33,8\% osób z wykształceniem poniżej wyższego). Nie jest to różnica jednoznaczna w wartościach bezwzględnych, jednak jest bar- 
dziej wyraźna w odniesieniu do wartości skrajnych — wśród osób z wykształceniem wyższym udział badanych, którzy deklarowali najniższe wartości udziału treści w języku niemieckim w konsumowanych treściach kultury, był istotnie niższy $(23,5 \%$ wobec $28,6 \%$ dla wskaźnika nasycenia o wartościach do $10 \%$ ).

Wykres 1. Rozkład badanych wg wartości wskaźnika udziału nasycenia treści kultury językiem niemieckim $\mathrm{w}$ grupach wyróżnionych ze względu na poziom wykształcenia (wyższe i poniżej wyższego).

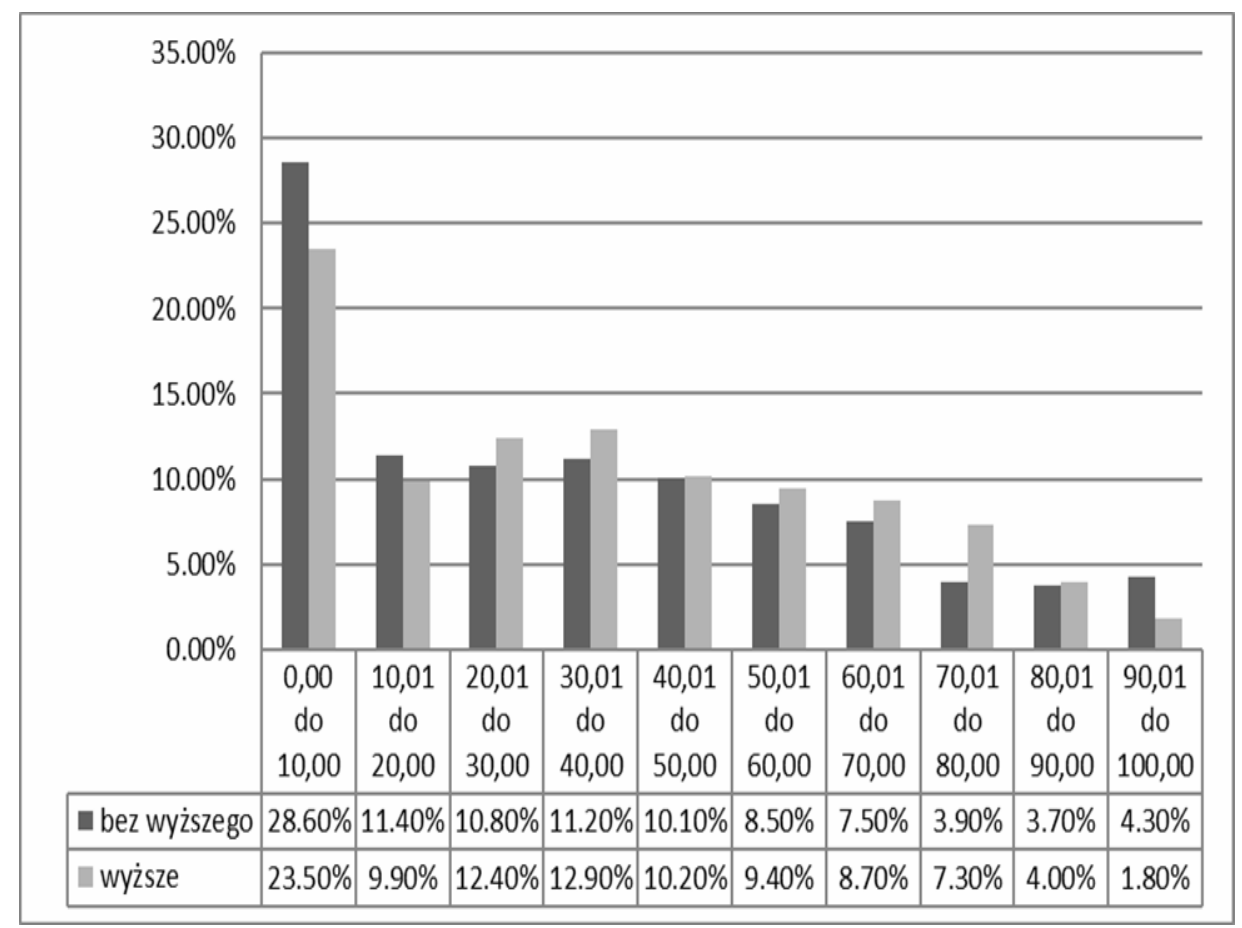

Źródło: obliczenia własne na podstawie badania.

Relatywnie niewielkie znacznie poziomu wykształcenia potwierdzają także wyniki analiz korelacyjnych przeprowadzonych w grupach badanych migrantów wydzielonych ze względu na poziom wykształcenia - jak to zaprezentowano w poniższej tabeli, korelacje pomiędzy wskaźnikiem nasycenia treściami w języku niemieckim a poszczególnymi charakterystykami badanych, ich migracji i uczestnictwa w kulturze pozostają podobne. Wyjątkiem jest kwestia poziomu wydatków na uczestnictwo w kulturze, które dla badanych migrantów bez wyższego wykształcenia nie stanowi czynnika istotnie skorelowanego ze wskaźnikiem nasycenia treści kultury językiem niemieckim, ale w grupie osób z wyższym wykształceniem okazało się istotne. Wydatki na kulturę związane są przede wszystkim z korzystaniem z ofert różnego rodzaju instytucji, można zatem sądzić, że w przypadku osób z wyższym wykształceniem dochodzi do bardziej jednoznacznego powiązania zanurzenia w kulturze niemieckojęzycznej z uczestnictwem instytucjonalnym. 
Tabela 4. Współczynniki korelacji pomiędzy wskaźnikiem nasycenia treści kultury językiem niemieckim a wybranymi cechami badanych i ich uczestnictwa w kulturze w podgrupach wyróżnionych ze względu na poziom wykształcenia.

\begin{tabular}{|l|c|c|}
\hline \multirow{2}{*}{ Czynniki } & \multicolumn{2}{|c|}{ Grupa } \\
\cline { 2 - 3 } & $\begin{array}{c}\text { Migranci z wyższym } \\
\text { wykształceniem }\end{array}$ & $\begin{array}{c}\text { Migranci z wykształceniem } \\
\text { poniżej wyższego }\end{array}$ \\
\hline $\begin{array}{l}\text { Deklarowany poziom } \\
\text { znajomości języka niemieckiego }\end{array}$ & $0,539^{* *}$ & $0,552^{* *}$ \\
\hline Długość pobytu & $0,471^{* *}$ & $0,467^{* *}$ \\
\hline Wiek & $0,279^{* *}$ & $0,271^{* *}$ \\
\hline $\begin{array}{l}\text { Wydatki na uczestnictwo } \\
\text { w kulturze }\end{array}$ & $0,115^{* *}$ & 0,068 \\
\hline
\end{tabular}

* Korelacja istotna na poziomie 0,05

** Korelacja istotna na poziomie 0,01

Źródło: obliczenia własne na podstawie badania.

Znaczenie walencji. Drugi objęty analizami czynnik różnicujący poziom nasycenia treści kultury językiem niemieckim to walencja kulturowa. W tym przypadku badani o deklarowanej walencji niemieckiej wykazywali istotnie wyższą (test U MannaWhitneya) wartość wskaźnika (45,3\% w porównaniu do $24,2 \%)$. Zróżnicowanie to można uznać za naturalną konsekwencję dokonywanych przez badanych wyborów tożsamościowych — poczucie przynależności raczej do kultury i społeczeństwa niemieckiego niż polskiego przekłada się $\mathrm{w}$ tym przypadku na znacznie intensywniejszy kontakt z niemieckojęzycznymi treściami kultury. Znaczenie walencji potwierdzają istotne różnice rozkładu wskaźnika intensywności nasycenia treściami kultury w języku niemieckim wśród obu grup — badani deklarujący polską walencję istotnie częściej deklarowali wartości niższe, tj. do $40 \%$ udziału, natomiast badanych deklarujących walencję niemiecką charakteryzuje rozkład bardziej równomierny, a przy wartościach wyższych (powyżej 40\% wartości wskaźnika nasycenia) są zdecydowanie liczniejsi. 
Wykres 2. Rozkład badanych wg wartości wskaźnika udziału nasycenia treści kultury językiem niemieckim w grupach wyróżnionych ze względu na deklarowaną walencję kulturową.

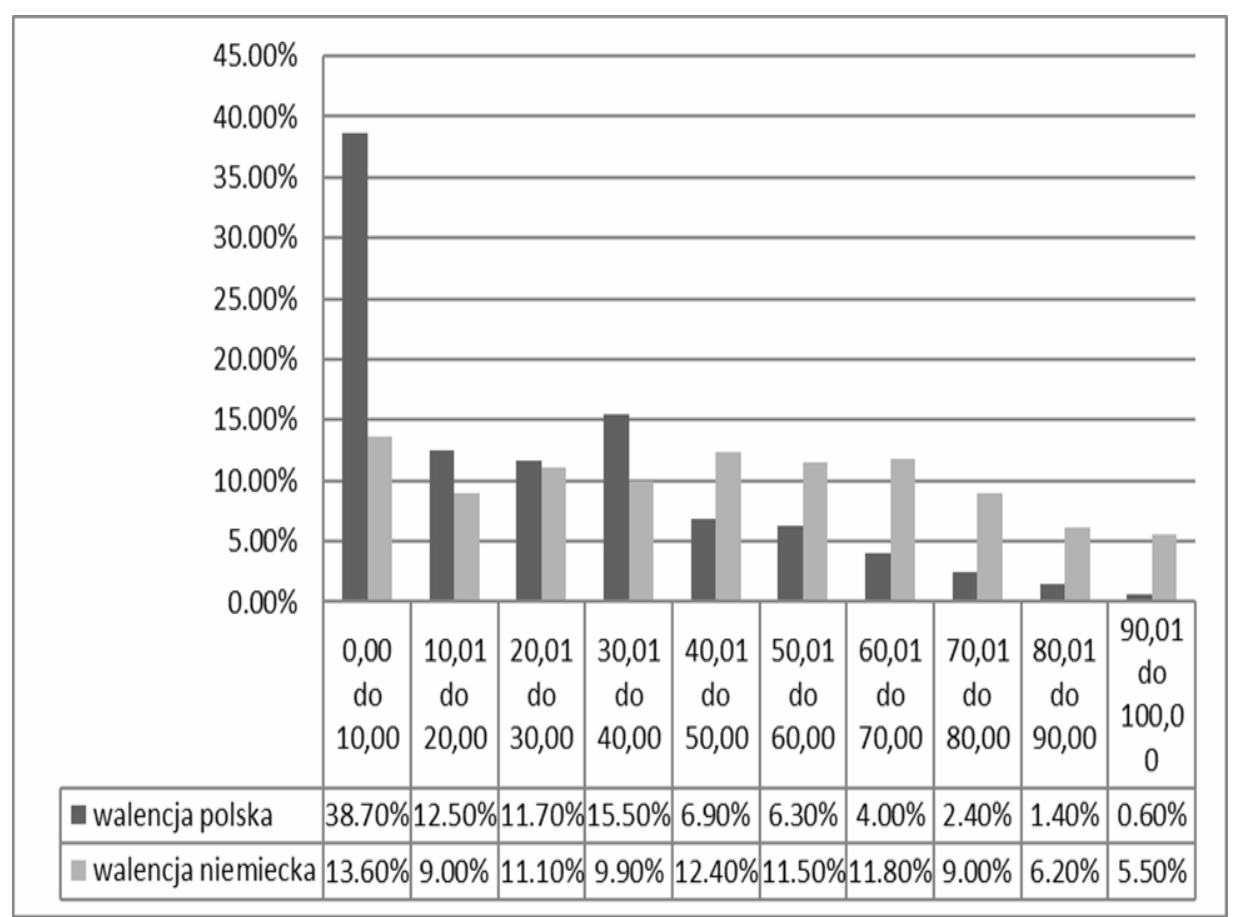

Źródło: obliczenia własne na podstawie badania.

Duże znaczenie różnicujące charakterystyki związków pomiędzy korzystaniem $\mathrm{z}$ treści kultury $\mathrm{w}$ języku niemieckim a wybranymi charakterystykami migrantów (ich pobytu i uczestnictwa w kulturze) potwierdzają różnice współczynników korelacji kierunki zależności pozostają analogiczne, ale w przypadku badanych deklarujących niemiecką walencję kulturową były one silniejsze w odniesieniu do długości pobytu, wieku i deklarowanego poziomu znajomości języka. Oznacza to, że w tej grupie dłuższy pobyt w Niemczech, wyższy wiek i lepsza znajomość języka niemieckiego silniej przekładają się na wartości wskaźnika nasycenia treści kultury językiem niemieckim. W żadnej z podgrup nie wystapiły natomiast istotne związki pomiędzy wydatkami na uczestnictwo w kulturze a nasyceniem treściami niemieckojęzycznymi. 
Tabela 5. Współczynniki korelacji pomiędzy wskaźnikiem nasycenia treści kultury językiem niemieckim a wybranymi cechami badanych i ich uczestnictwa w kulturze w podgrupach wyróżnionych ze względu na walencję kulturową.

\begin{tabular}{|l|c|c|}
\hline \multirow{2}{*}{\multicolumn{1}{|c|}{ Czynniki }} & \multicolumn{2}{|c|}{ Grupa } \\
\cline { 2 - 3 } & $\begin{array}{c}\text { Migranci deklarujący } \\
\text { walencję niemiecką }\end{array}$ & $\begin{array}{c}\text { Migranci deklarujący } \\
\text { walencję polską }\end{array}$ \\
\hline $\begin{array}{l}\text { Deklarowany poziom znajomości } \\
\text { języka niemieckiego }\end{array}$ & $0,535^{* *}$ & $0,477^{* *}$ \\
\hline Długość pobytu & $0,461^{* *}$ & $0,337^{* *}$ \\
\hline Wiek & $0,306^{* *}$ & $0,129^{* *}$ \\
\hline $\begin{array}{l}\text { Wydatki na uczestnictwo } \\
\text { w kulturze }\end{array}$ & 0,064 & 0,067 \\
\hline
\end{tabular}

* Korelacja istotna na poziomie 0,05

** Korelacja istotna na poziomie 0,01

Źródło: obliczenia własne na podstawie badania.

\section{Wnioski}

Odnosząc się do przedstawionych wyników, należy wskazać, że pogłębiają one główne zależności zidentyfikowane w projekcie. Zgodnie z przedstawioną chociażby przez Renatę Suchocką ${ }^{19}$ listą czynników istotnych dla stosowanych strategii adaptacyjnych, umiarkowanie ważny okazał się poziom wykształcenia migrantów, w pewnym zakresie intensyfikujący oddziaływanie na włączenie migrantów (pod względem językowym) w kulturę niemiecką takich czynników jak wiek, długość pobytu czy poziom znajomości języka. W tym ostatnim przypadku można sądzić, że zależność ma charakter cyrkularny — lepsza znajomość języka pozwala na intensywniejsze korzystanie z przekazów niemieckojęzycznych, a jednocześnie korzystanie z nich poprawia poziom znajomości języka.

Czynnikiem o wyraźniejszym znaczeniu okazała się jednak walencja kulturowa, której znaczenie wiąże się z kwestiami tożsamościowymi migrantów (jeśli stosować pojęcia socjologiczne) albo akulturacją (jeśli wykorzystywać pojęcia psychologii międzykulturowej). Zastosowanie wymuszonej deklaracji uniwalencji sprawia, że tożsamość migrantów jawi się jako (pozornie) jednolita, jednak przytoczone wartości wskaźnika nasycenia treści kultury językiem niemieckim pozwalają zauważyć złożoność tożsamości przejawiającą się z jednej strony — deklaracją bliskości jednej z kultur, z drugiej zaś — sięganiem przez większość migrantów z treści zarówno polsko-, jak i niemieckojęzyczne, a więc odwołujące się w mniejszym lub większym zakresie do tradycji kultury polskiej i niemieckiej (mniejszym lub większym, ponieważ język przekazu nie jest tożsamy z pochodzeniem danej treści). Badania wskazują na powszechność biwalencji i na jej wpływ na tożsamość migrantów ${ }^{20}$. Uzyskane wyniki wskazują

${ }^{19}$ R. Suchocka, Migranci pomiędzy dwiema kulturami.

${ }^{20}$ Por.: W. Nowak, Problemy tożsamości społecznej Polaków; S. Schindler, M.-A. Reinhard, M. Knab, D. Stahlberg, The Bicultural phenomenon. The Interplay of group prototypicality and 
więc na złożoność identyfikacji, jaką ujawnia uwzględnienie jednocześnie deklaratywnego uznania jednej z kultur za bliską i własną (wymiar poznawczy i emocjonalny) i opisywanych praktyk uczestnictwa w kulturze (wymiar zachowań). Wykorzystanie łącznie tych wymiarów i wskazanie na złożoność procesów uczestnictwa w kulturze, jakie charakteryzuje migrantów z Polski w Niemczech, pozwala przy tym na wskazanie celowości włączania dziedzictwa teorii socjologicznych (m.in. z zakresu socjologii kultury) w badania migrantologiczne. Analogicznie psycholodzy międzykulturowi podkreślają złożoność procesów tożsamościowych, jakich doświadcza jednostka w sytuacji migracyjnej - ich zależność od otoczenia społecznego, przekazu i kontekstu kulturowego pozwala uznać ten obszar za wspólny przedmiot zainteresowania tak socjologii, jak i psychologii. Powszechność doświadczania migracji (w społeczeństwach przyjmujących — kontaktu z przedstawicielami innych kultur), za którą odpowiadają m.in. ${ }^{21}$ rosnące znaczenie czynników skłaniających ludność do przemieszczania się, technologiczny rozwój ułatwiający i obniżający koszty przemieszczania się, a także kulturowa akceptacja mobilności w zglobalizowanym świecie i doświadczanie wielokulturowości lub wręcz postulowana przewaga „paradygmatu” mobilności nad osiadłością ${ }^{22}$, przemawiają za głębszymi analizami zagadnień akulturacji, uczestnictwa w kulturze i tożsamości wraz z rozpoznawaniem wpływających na nie czynników.

\section{LITERATURA}

Boski P., Kulturowe ramy zachowań społecznych. Podręcznik psychologii międzykulturowej. Warszawa 2009;

Dawidenko O., Polonia na tle procesów narodowościowych Kazachstanu. Wymiary identyfikacji narodowej, http://janek.uek.krakow.pl/ limes/files/el1(1)2002/od_limes1(1).pdf [dostęp: 10.01.2020];

Filiciak M., Danielewicz M., Halawa M., Mazurek P., Nowotny A., Młodzi i media. Nowe media a uczestnictwo w kulturze, Warszawa 2010;

Grzymała-Kazłowska A., Ku socjologii mobilnego społeczeństwa? Rozwój koncepcji migracji i integracji a socjologia, Studia Socjologiczne $2013 \mathrm{nr}$ 210, s. 31-52;

Jeran A., Nowak W., Nowosielski M., Popławski M., Migranci z Polski w Niemczech — aspekty kulturowe. Raport z badań ilościowych. Warszawa: Ośrodek Badań nad Migracjami, 2019, http://www.migracje.uw.edu.pl/publication_type/publikacje-raporty/ [dostęp: 10.01.2020];

Jeran A., Nowosielski M., Nowak W., Migranci z Polski w Niemczech - aspekty kulturowe. Raport z badań. Warszawa: Ośrodek Badań nad Migracjami, 2019, http:// http://www.migracje.uw.edu.pl/publication_type/publikacje-raporty/ [dostęp: 10.01.2020];

Jeran A., Prolegomena: głos w obronie tradycji albo dlaczego uczestnik to nie zombie, [w:] Diagnoza systemu kultury Bydgoszczy, red. taż, Bydgoszcz 2012, s. 11-24;

Kisiel P., Wspótczesne wzory uczestnictwa w kulturze, [w:] Kultura a rozwój, red. J. Hausner, A. Karwińska, J. Purchla, Warszawa 2013, s. 345-360;

A. Kłoskowska, Kultury narodowe u korzeni, Warszawa 2012;

-, Spoteczne ramy kultury. Monografia socjologiczna, Warszawa 1972;

Lesińska M., Polska diaspora, Polonia, emigracja. Spory pojęciowe wokót skupisk polskich za granica, The Polish Migration Review 2018 nr 1 (3), s. 9-23;

Nowak W., Problemy tożsamości społecznej Polaków mieszkających w Niemczech, Przegląd Zachodni $2013 \mathrm{nr}$ 3, s. 257-271;

cultural identity switching, Social Psychology 2016 nr 47, s. 233-243, https://doi.org/10.1027 /1864-9335/a000276.

${ }^{21}$ A. Sakson, Migracje - fenomen XX i XXI wieku, Przegląd Zachodni 2008 nr 2, s. 11-19.

${ }^{22}$ A. Grzymała-Kazłowska, Ku socjologii mobilnego społeczeństwa? Rozwój koncepcji migracji i integracji a socjologia, Studia Socjologiczne 2013 nr 210, s. 31-52. 
Nowosielski M., Polacy w Niemczech. Stan i perspektywy badań, Przegląd Zachodni 2012 nr 3, s. 3-28;

Nycz E., Dziedzictwo kulturowe a adaptacja starych i nowych migrantów z Polski w spoleczeństwie niemieckim, Zeszyty Naukowe Politechniki Śląskiej, seria: Organizacja i Zarządzanie $2018 \mathrm{nr}$ 126, s. 161-172;

Sakson A., Migracje - fenomen XX i XXI wieku, Przegląd Zachodni 2008 nr 2, s. 11-19;

Schindler S., Reinhard M.-A., Knab M., Stahlberg D., The Bicultural phenomenon. The Interplay of group prototypicality and cultural identity switching, Social Psychology $2016 \mathrm{nr} 47$, s. 233-243, https://doi.org/10.1027/1864-9335/a000276;

Schulz M., Migracje ekonomiczne Polaków do Niemiec, Humanizacja Pracy 2013 nr 272, s. 73-86;

Slany K., Strzemecka S., Who are we? Cultural valence and childrens narratives of national identifications, Central and Eastern European Migration Review 2016 nr 1 (5), s. 13-34, http://doi.org/10.17467/ceemr.2016.03;

Suchocka R., Migranci pomiędzy dwiema kulturami i pomiędzy dwiema strategiami adaptacyjnymi, Ruch Ekonomiczny, Prawniczy i Socjologiczny, 2013 z. 1, s. 249-265.

\section{GERMAN LIFE, POLISH CULTURE - FACTORS DIFFERENTIATING THE LEVEL OF INCLUSION INTO THE GERMAN-LANGUAGE CULTURE AMONG POLISH IMMIGRANTS IN GERMANY}

Germany is one of the traditional destinations for Polish labour migrants. The subsequent waves of immigrants resulted in a formation of a large diasporic community, currently estimated at about 1.3 million. Broadly understood participation in culture - including both mass culture (in German, Polish, and other languages) and activities of both German and Polish diasporic cultural institutions - is considered particularly important in the context of social integration of migrants. This particular aspect of immigrant experience was a subject of a recent study - over 1200 Polish migrants were asked about their experiences via an online study. Their answers allowed to distinguish factors determining the level of inclusion into the German-language culture. The results of the survey indicate that the most determinantal factors facilitating participation in cultural content presented in German are the level of education and cultural valance declared by the migrant. Out of the two, cultural valance is a more influential one as it has a much stronger impact on the language characteristics of participation in culture.

KEY WORDS: migrants from Poland in Germany, cultural valence, participation in culture

\section{NIEMIECKIE ŻYCIE, POLSKA KULTURA - CZYNNIKI RÓŻNICUJĄCE POZIOM KORZYSTANIA $Z$ NIEMIECKICH TREŚCI KULTURY WŚRÓD MIGRANTÓW Z POLSKI W NIEMCZECH}

Niemcy stanowią jeden z tradycyjnych kierunków migracji zarobkowej z Polski. Kolejne fale tworzą liczną społeczność — szacowaną obecnie na około 1,3 mln. W kontekście integracji społecznej migrantów szczególne znaczenie ma szeroko rozumiane uczestnictwo w kulturze obejmujące korzystanie z kultury masowej (w języku niemieckim, polskim i innych) oraz z ofert instytucji kultury, zarówno niemieckich, jak i ukierunkowanych na polską kulturę, a prowadzących działalność w Niemczech. Ten aspekt doświadczeń migracyjnych objęto badaniem, w którym udział - dzięki ankiecie internetowej - wzięło ponad 1200 migrantów. Ich odpowiedzi pozwalają na scharakteryzowanie czynników różnicujących zakres, w jakim dokonuje się włączenie w kulturę niemieckojęzyczną lub pozostanie przy korzystaniu z treści kultury w języku polskim. Wyniki pozwalają wskazać, że czynnikami istotnymi dla intensywniejszego korzystania $\mathrm{z}$ treści kultury w języku niemieckim są m.in.: poziom wykształcenia migranta i deklarowana przez niego walencja kulturowa, przy czym walencja kulturowa znacznie silniej oddziałuje na charakterystyki językowe uczestnictwa w kulturze.

Słowa kluczowe: migranci z Polski w Niemczech, walencja kulturowa, uczestnictwo w kulturze 